\title{
Prasentation af CRTT - Centre de Recherche de Ter- minologie et de Traduction fra Université Lyon II og CTN - Centre de Terminologie et de Néologie i Paris
}

På Université Lyon II findes et forholdsvist nyt forskningscenter for terminologi og oversættelse - Centre de Recherche de Terminologie et de Traduction - CRTT - under ledelse af anglicisten Philippe Thoiron. Her samles forskere, licentiatstuderende og andre interesserede i et debatforum, og der bliver lavet terminologi i samarbejde med bl.a. den kemiske industri i området.

Med centrets egne ord er formålet:

"Le centre de recherches en terminologie et traduction, créé en juin 1986, a pour objectif d'encourager le développement des recherches multilingues principalement dans le domaine de la terminologie et de la traduction et a également pour mandat de s'occuper de la formation des étudiants au doctorat. Il permet la mise en commun des compétences de chercheurs lesquelles proviennent, pour la plupart, des universités de la région et travaillent en collaboration avec des chercheurs étrangers. Les actions et projets reconnus par le Centre combinent travaux théoriques et applications pratiques et laissent une large part à l'emploi des outils informatiques.

Le CRTT comporte deux composants complémentaires: un Bureau de Terminologie Multilingue, associé au Département de Langues Etrangères Appliquées, et un Bureau de Traduction et d'Enseignement avec Aides Informatiques, associé au Département d'Etudes Arabes. Il regroupe présentement une vingtaine de chercheurs et bénéficie de la possibilité d'accès aux grandes banques de données terminologiques multilingues."

* Susanne Lervad

Département des Etudes Allemandes et Scandinaves

Université Lyon II

Avenue Pierre Mendès France

69676 Bron Cedex $(F)$ 
Så meget om målsætningen for centrets arbejde. Hvad angår publicerede arbejder og projekter samt igangværende forskning kan der fra terminologiafdelingen nævnes:

\section{"Bureau de Terminologie Multilingue:}

- Dictionnaire informatisable anglais-français d'écologie des eaux continentales.

- Dictionnaire informatisable anglais-français de pharmacologie

- Participation au projet lexicographique de Oxford University Press

- Mise au point des articles consacrés aux termes spécialisés." og fra oversættelsesafdelingen:

\section{"Bureau de Traduction et d'enseignement avec aides informatiques:}

- Formalisation de la langue arabe et terminologie arabe. Préparation du cadre théorique d'un vocabulaire général de l'arabe.

- Traitement automatique de l'arabe. Réalisation d'un prototype de la conjugaison.

Les chercheurs du Bureau ont travaillé à l'établissement de vocabulaires arabes de spécialité (télécommunication, micro-informatique, optique) et doivent préparer ensemble une définition théorisée de ces vocabulaires."

Som dansk lektor ved det skandinaviske institut på universitetet i Lyon, hvor jeg hovedsagelig underviser i dansk sprog og kultur, er jeg kommet i kontakt med CRTT via det forskningsprojekt om tekstilterminologi, som jeg også er ansat til at beskæftige mig med.

Lyon er traditionelt et vigtigt centrum for handel og industri. Byen har en flere hundrede år gammel fin silkevævningstradition, der er efterfulgt af en stor tekstilkemisk industri, især inden for kemofibre og tekniske tekstiler, idet der er meget kemisk industri i Rhône-dalen, hvor bl.a. det store kemifirma Rhône-Poulenc holder til. Denne industri gør Lyon til en rig by, og med en størrelse som København er Lyon kraftcenter i hele Rhône-Alpes regionen.

Forskningscentret CRTT har for nylig udgivet sin første samlede publikation: Aspects du Vocabulaire. Bidragyderne er både leksikografer og terminologer fra Département de Langues Etrangères Appliquées - LEA, og denne første publikation er præget af centrets specielle sammensætning af arabiske sprogstudier og især engelsk/fransksproget sprogforskning. Bogen behandler terminologiske aspekter, men også mere lek- 
sikografiske og psykolingvistiske aspekter med applikationer i fransk, arabisk, engelsk, spansk og portugisisk.

I praksis er centret altså opdelt i to sektioner - en multilingval terminologisektion, der har LEA-tilknytning via engelsk institut og med forskningsstuderende, og en oversæettelsessektion, der er knyttet til afdelingen for arabiske studier. Centret grupperer ca. 20 forskere, der arbejder i dette forum med seminarer og uddannelse af forskere. "Aspects du Vocabulaire" er præget af denne sammensætning, idet den ene del af bidragene stammer fra LEA-undervisning og forskning og den anden del fra de arabiske sprogstudier.

Centret modtager mange udenlandske forskere til workshops og den årlige seminarrække fra december til juni. Meget af centrets arbejde foregår sammen med canadiske forskere med udgivelse af artikler i tidskriftet Meta fra Montréal.

Der er også stor interesse for samarbejde med nordiske sprogforskere. Université Lyon II har samarbejdsaftale med Universitet og Handelsh $\varnothing j$ skolen i Århus, og der udveksles hvert år et antal studerende. Der opfordres til nordisk gæsteoptræden på fransk i dette forum, og interesserede kan enten henvende sig til lederen af CRTT: Philippe Thoiron eller til kontaktpersonen til Handelshøjskolen i Århus: Henri Béjoint.

En kort præsentation af forskernes arbejde findes i den nyeste publikation fra centret: Aspects du Vocabulaire, som indeholder en række artikler fra den anglicistiske fløj og en række artikler fra den arabiske sprogverden.

P. Arnaud indleder bogen med artiklen : "Estimations subjectives des fréquences des mots en L1 et L2". Ud fra sprogdidaktiske erfaringer giver han et historisk psykolingvistisk rids over L1's omnipræsente tilstedeværelse i institutionnelle indlæringsprocesser.

Henri Béjoint fortsætter med "La définition en terminographie" - en spændende problematiserende artikel om definitionens plads i terminologiarbejde. Han opstiller en sammenligning mellem en leksikografisk og en terminologisk definition. Han skelner mellem "définitions dictionnairiques" fra fagordbøger og "définitions textuelles", som man finder dem i vejledninger og andre fagtekster.

Ideelt set skulle terminologiske definitioner være mere præcise og komplette end leksikografiske, men Béjoint lægger op til en diskussion af hvorvidt dette er tilfældet. Han sætter spørgsmålstegn både ved præci- 
sionen og den udtømmende karakter ved definitioner i terminologiarbejde.

Der gennemgås endvidere forskellige former for definitioner, men især generiske definitioner med en lang række relevante og gode eksempler. Béjoint ender han med at fastslå at definitioner i terminologi generelt er svære at forstå - at deres forklarende værdi er ringe. De opfylder kun tilsyneladende de generiske definitioners krav og den formodede større præcison i denne type defintioner er ikke reel. Det er et provokerende og forfriskende udspil fra en leksikografs side, der efterlyser mere diskussion om kriterierne for arbejde med definitioner i terminologiarbejde for at kunne opnå konsekvente, sammenhængende og præcise definitioner.

Phillipe Thoiron står for en artikel om kvantitativ analyse af videnskabelige tekster: "Analyse quantitative des textes scientifiques". Han gennemgår den historiske udvikling af kvantitative undersøgelser fra litterære tekster til faglitteratur og videnskabelige tekster. Han gennemgår udviklingen i tekstbaser og statistiske metoder.

Fra den anglicistiske side er det mest vægtige bidrag Uzoma Chuwkus artikel om terminologi inden for informatikverdenen. "La terminologie informatique: à la recherche de clés d'accès".

Chuwku har lige afsluttet sin afhandling om "repérage des termes dans un corpus bilingue - français-anglais", og artiklen behandler problemstillinger fra denne aktuelle korpusdiskussion.

Han har trukket et stort eksempelmateriale af både syntagmer og akronymer ud af tidssskriftsartikler og informatikordbøger i en erkendelelse af, at informatikverdenen i højere og højere grad bliver sprogmedarbejderens arbejdsfelt.

Han behandler især akronymets rolle - dets semiotiske funktion og forholdet mellem de syntagmatiske termer i informatikkens terminologi og transparensen og effektiviteten i de endeløse forkortelser.

Chuwkus udgangspunkt er "arabisten" André Romans modus-res teori.

André Roman gennemgår selv sin teori i artiklen "La voie des hypertextes". Hans gennemgang af de semitiske sprogs karakteristika sker med eksempler fra hans teori om tidsafhængige og tidsuafhængige sproglige former. Han har også pointer om stigende opacitet i sproget og den fordel hypertekt kan give for at imødekomme dette. 
Andre bidrag fra de arabiske forskere er: Xavier Lelubres artikel om græsk-latinske grundelementer i fransk og engelsk terminologi stillet over for en arabisk orden: "Les relations d'ordre en arabe entre les éléments d'unités terminologiques simples à formants greco-altins en français et en anglais. Fra hans område, laseroptik, illustreres forskellene mellem arabisk termdannelse og den græsk-latinske tilgang til termdannelse i fransk og engelsk.

Hassan Hamzé slutter denne arabiske afdeling af med artiklen om brugen af passiv i arabisk: "La traduction de la voix objective entre le français et l'arabe" med en lang række sammenlignende eksempler fra fransk og arabisk.

Herudover er der to bidrag vedrørende andre romanske sprog, nemlig om portugisisk inflations $\emptyset$ konomisk terminologi af Maria Eugênia Malheiros Poulet: "L'utilisation du métaphore comme procédé de divulgation du phénomène de l'inflation dans l'hébdomadaire VEJA” og Jean-Jacques Montelascauts artikel om medicinsk terminologi i spansk presse: "Le langagae médical dans la presse espagnole".

Forhåbentlig kan denne korte omtale være en appetitvækker for den i Danmark temmelig ukendte arabiske sprogforskning, som der på CRTT er gode muligheder for at stifte bekendtskab med i parløb med den fransk /engelske sprogforskning.

Jeg vil slutte af med en omtale af et parisisk forskningscenter for terminologi, der også er meget nordisk orienteret, nemlig af CTN - Centre de Terminologie et de Néologiei Paris

Leder: John Humbley (mangesproget og bl.a. dansktalende franskmand!).

Øvrige medarbejdere: G. Otman, E. Blanchon, J. Boissy samt flere free-lance tilknyttede medarbejdere.

CTN blev oprettet i 1987 som en underafdeling til Institut de la langue française (INaLF) og Centre National de la Recherche Scientifique (CNRS).

Centret varetager følgende arbejdsopgaver:

- Udarbejdelse af sektorterminologier f.eks. AI, robotique.

- Uddannelse og forskning inden for terminologi/neologi.

- Samarbejde med ministerier og standardiseringsorganer som AFNOR.

- Registrering af neologi inden for videnskab og teknik. 
- Oprettelse af dokumentationsafdeling.

- Medvirken i RINT: Réseau International de Néologie et de Terminologie.

- Undersøgelser af behovet for terminologiarbejde i virksomheder og organisationer.

- Teoretiske og metodiske bidrag til den internationale udveksling af forskning inden for terminologiens relation til grænseområder, f.eks. AI.

- Afprøvning af systemer/software til terminologiarbejde

- Udgivelse af tidsskriftet Banque de Mots

- Udgivelse af Cahier des Termes Nouveaux, 1991, 1992, 1993

CTN er et meget åbent sted, hvor alle interesserede er velkomne til at komme og afprøve de meget store canadiske termbanker TERMIUM og BQS. De har et lille udvalg af CD-ROM ordbøger og en meget fin samling af specialordbøger med alt fra Wüsters værktøjsordbøger til ordbøger om kunstig intelligens og robotterminologi.

Centret råder over en række databaseprogrammer til terminologiarbejde, f.eks. Texto, MC4 og Aquila for at nævne nogle franske samt de for danske terminologi-interesserede mere velkendte som TERMPC og Termex.

Centret har en god kontakt til det canadiske terminologiarbejde.

I Canada er der ofret mange millioner på at ajourføre fagsprogenes terminologi, og resultatet er både de store termbanker som TERMIUM og BQS samt mange enkeltudgivelser (fagordbøger fransk-engelsk), som findes på centret. Desuden har de spændende tidsskrifter fra Canada.

Lederen J. Humbley har også en god kontakt til terminologiarbejde i Danmark via sin forståelse af dansk. Han vil gerne have alt relevant materiale om sprogligt arbejde i Danmark til sin dokumentationsafdeling, som i forvejen rummer en del dansk - noget man ikke er forvænt med i Frankrig.

Centret har sporadisk modtaget Hermes og $A R K$ og vil gerne opfordre de danske tidsskriftsredaktioner til at sætte CTN på deres mailingliste!

Hvis der i sproglige kredse i Danmark er interesse for et besøg hos CTN og J. Humbleys gruppe er adressen:

Université Paris Nord

CTN

Avenue J. Jaurès

F-93240 Villetanneuse 
Jeg vil gerne formidle kontakt til de to forskningscentre og kan træffes på følgende adresse:

Susanne Lervad, ph.d. (Tekstilterminologi)

Université Lyon II

Département des Etudes Allemandes et Scandinaves

Avenue Pierre Mendès France

F-69676 Bron Cedex 